\title{
Detection of Glucomacropeptide in Raw Milk Adulterated with Cheese Whey in Ecuador
}

\author{
Byron Humberto Puga-Torres ${ }^{1,2^{*}}$, Samantha Michele Morales-Arciniega ${ }^{1}$, \\ Luis Fabián Núñez Naranjo 1,3, David Isaías De la Torre-Duque ${ }^{1,3}$, \\ Rolando Martin Campos-Vallejo ${ }^{4}$, Silvana Hipatia Santander-Parra ${ }^{3}$, \\ Enrique César Vayas-Machado ${ }^{2}$
}

\begin{abstract}
${ }^{1}$ School of Veterinary Medicine and Animal Science, Central University of Ecuador, Quito, Ecuador ${ }^{2}$ School of Engineering of Livestock Industries, Chimborazo Polytechnic School, Riobamba, Ecuador

${ }^{3}$ Department of Experimental and Comparative Pathology, School of Veterinary Medicine and Animal Science, University of São Paulo, São Paulo, Brazil

${ }^{4}$ Career of Integral Agricultural Development, Faculty of Agricultural Industries and Environmental Sciences, Carchi Polytechnic University, Tulcán, Ecuador

Email:^bpuga@uce.edu.ec
\end{abstract}

How to cite this paper: Puga-Torres, B.H., Morales-Arciniega, S.M., Naranjo, L.F.N., De la Torre-Duque, D.I., Campos-Vallejo, R.M., Santander-Parra, S.H. and Vayas-Machado, E.C. (2017) Detection of Glucomacropeptide in Raw Milk Adulterated with Cheese Whey in Ecuador. Food and Nutrition Sciences, 8, 579-590.

https://doi.org/10.4236/fns.2017.86040

Received: April 27, 2017

Accepted: June 4, 2017

Published: June 7, 2017

Copyright $\odot 2017$ by authors and Scientific Research Publishing Inc. This work is licensed under the Creative Commons Attribution International License (CC BY 4.0).

http://creativecommons.org/licenses/by/4.0/ (c) (i) Open Access

\begin{abstract}
Milk is one of the products that can be adulterated in many ways affecting the quality of this and its derivatives. Glucomacropeptide (GMP) is a protein that is found only in the whey from the production of fresh cheese, enzymatically obtained from the coagulation of casein and which is commonly used to adulterate fresh or powdered milk. The aim of this study was to determine the adulteration of milk with cheese whey thought a molecular approach, where the glucomacropeptide was collected by sequential precipitation with trichloroacetic acid (ATC) and detected by polyacrylamidododecylsulfate gel electrophoresis (PAGE-SDS), using samples of fresh milk, intentionally adulterated with serum in the proportion of $0 \%, 1 \%, 5 \%, 10 \%$ and $15 \%$. The results obtained showed that the detection of glucomacropeptide by electrophoresis was positive in all samples of adulterated milk, evidencing a band of $20.9 \mathrm{kDa}$ in the reading, corresponding to the molecular weight of the GMP, showing that the technique used determines the adulteration in the milk, in a specific and sensitive way, also shows that in the evaluation of physical-chemical and microbiological parameters of milk, there are no significant differences between treatments, except for the $\mathrm{pH}$ that tends to decrease as the percentage of serum in the milk increases.
\end{abstract}

\section{Keywords}

Glucomacropeptide, Raw Milk, Whey Cheese, Milk Adulteration 


\section{Introduction}

For Codex Stan 206 [1], milk is the "normal mammary secretion of dairy animals obtained by one or more milks without any addition or extraction, intended for consumption in the form of liquid milk or further processing". The Ecuadorian Technical Standard INEN 0009:15 [2] in its Sixth Review, indicate that milk "is the product of normal mammary gland secretion, obtained from the healthy and complete milking of healthy cows, without adding or any removal, free of colostrum and free from materials extraneous to their nature, intended for consumption in its natural form or for later processing". Whey milk according to Codex Stan 289 [1] is the "liquid dairy product obtained during the manufacture of cheese, casein or similar products, by separating the curd, after the milk coagulation and/or products derived from milk". The Ecuadorian Technical Standard INEN 2401:2008 [3] indicates that whey "is the liquid milk product obtained during the manufacture of cheese, casein or similar products, by separating the curd, after the coagulation of pasteurized milk and/or products derived from pasteurized milk; coagulation is obtained by the action, mainly of rennet enzymes".

One of the main components of milk is protein, which together with enzymes are composed of amino acids [4]. The percentage of proteins is between $2.8 \%$ and $3.5 \%$, of which about $80 \%$ corresponds to the caseins [5] which combine with calcium and phosphate giving the colloidal form to milk and constituting the essential part for cheese elaboration, [6] the most important of which are $\alpha, \beta$ and $\kappa$ (kapa) [5], although in fact six types of caseins are reported: $\alpha$ s1 (alpha s1), $\Gamma$ (gamma), $\kappa$ (kappa) and $\lambda$ (lambda) [6]. If the milk is acidified to $\mathrm{pH}$ of 4.7, calcium and phosphate are separated from casein, becoming insoluble and depositing; on the other hand, soluble albumin and globulin become insoluble with heating at more than $65^{\circ} \mathrm{C}$, causing protein denaturation [4]. Calcium salts of $\alpha$-casein and $\beta$-casein are almost insoluble in water, whereas those of $\kappa$-casein on the surface of the micelles are normally soluble [7], because the latter has insensitivity to ion precipitation Calcium, remains soluble in solutions of calcium with concentrations that precipitate all other caseins, is also susceptible to hydrolysis by chymosin (enzymatic coagulation pathway), and is the only one containing cysteine and carbohydrate residues in its structure [6].

The enzymatic pathway of coagulation is given by renin or chymosin (produced in the abomasum of lactating ruminants) or other coagulant or proteolytic enzymes (pepsin, bacterial and plant enzymes) [5] on the amino acid chain that forms the $\kappa$-casein molecule (which consists of 169 amino acids), specifically at the link between amino acids 105 (phenylalanine) and 106 (methionine) which is particularly weak [8]. Once the amino acid chain is broken, the part containing amino acids 106 to 148 contains all the carbohydrates of $\kappa$-casein, called macropeptide [7], therefore, the glucomacropeptide (or also known as GMP) is released to the whey by the action of the renin on the $\kappa$-casein during the elaboration of the cheese, being able to constitute an indicator of adulteration of milk with cheese whey [6]. The remaining part of $\kappa$-casein is called para- $\kappa$-casein and 
consists of amino acids 1 to 105, having the particularity of being very insoluble and therefore remaining with the $\alpha$ and $\beta$ caseins in the cheese cloth, which is formed due to the sudden removal of the hydrophilic macropeptide and the imbalance that this causes [7].

GMP is therefore a 64-amino acid peptide, present exclusively in whey cheese, released after the specific cleavage of $\kappa$-casein by chymosin; consists of two non-glycosylated isoforms (aGMP A and aGMP B) and their different glycosylated forms (gGMP A and gGMP B), the most predominant carbohydrate of gGMP being N-acetylneuraminic acid (sialic acid) [9]. It should be noted that some psychotropical microorganisms (especially Pseudomonas fluorescens) when present in stored milk may produce enzymatically a GMP-like peptide, generally called pseudo-GMP; these two peptides differ from each other only by one amino acid [10].

Studies have shown that GMP helps the production of cytokines, regulating immune system interactions [11], is an immunomodulator that has an intestinal anti-inflammatory effect in rats with colitis type I [12] [13] [14], has gastric inhibitory activity [15] and is used for the nutritional management of phenylketonuria in humans [16] [17] [18], has a gastric inhibitory activity, because it lacks aromatic amino acids, making it usable as a nutritional supplement for these people [9]. Studies also show that GMP has anti-inflammatory, prebiotic and immunomodulatory effects, including for atopic dermatitis in humans [19].

Therefore, the adulteration of milk with whey from cheeses is not a public health problem; however it is considered a fraud [8], especially in raw milk, because according to INEN Standard 9 [2] it should not have any type of addition or extraction. Besides being a consumer fraud, adulteration with whey milk is considered unfair competition to the producer and affects the milk chain production [20]. There are serious problems with this adulteration, which is faced by the marketing and processing industries, because the low cost of the whey and because it is sensorially very similar to milk, the whey is difficult to determine with routine physicochemical methods of milk quality control [21].

There are several methods to determine adulteration of milk with cheese whey, among which we can mention indirect methods that are based on the determination of the proportion of whey casein present in milk, which is done through: quantification of no casein nitrogen analysis, quantification of sulfhydryl groups per gram of protein, determination of ammonium levels in milk using a potentiometer, and determination of the cysteine-casein complex, using a polarographic method [8]. Among the direct methods is the detection of GMP as an adulteration biomarker (Campos Mottaa et al., 2014), since it is not possible to find it in free form in milk unless it contains added whey [8]-[21]. In Ecuador, the Ecuadorian Technical Standard INEN 2401:2008 [3] indicates that the determination of cheese whey in liquid and powdered milk must be carried out using the High Performance Liquid Chromatography (HPLC) method. Another method corresponds to the detection of an ELISA system through commercial kits [21].

The objective of this investigation was to detect GMP in milk adulterated with 
whey through sodium dodecylsulfate polyacrylamide gel electrophoresis (SDSPAGE) and to determine whether there is or not alteration of the physicochemical and bacteriological properties of adulterated milk.

The importance of the study is to verify and thus to provide the dairy industry with a reliable method for determining the adulteration of raw milk with cheese whey (the practice of which is very common), since this constitutes cheating and fraud for the buyer, which directly affects the production of dairy products, due to the reduction of natural components of milk, which are necessary to improve performance in the dairy industry, avoiding economic losses to it.

\section{Methodology}

This research was carried out at the Polytechnic School of Chimborazo, located in the Riobamba city (to $190 \mathrm{~km}$ from Quito), province of Chimborazo-Ecuador.

\subsection{Factors of Study}

In the present study, milk from a single commercial house and dairy cheese whey was used, based on the NTE INEN 4 [22]; four intentional adulterations were performed at different concentrations and one control (T0) with whole milk (5 samples), with four replicates, giving a total of 20 experimental units (Table 1) which is calculated from the 5 treatments multiplied by 4 repetitions each. It was done under a completely random design. The treatments under study were:

- T0: Fresh milk without adulteration;

- T1: Milk adulterated with $1 \%$ whey;

- T2: Milk adulterated with 5\% whey;

- T3: Milk adulterated with $10 \%$ whey;

- T4: Milk adulterated with $15 \%$ whey.

The variables that were evaluated were: milk adulteration determination by GMP detection, physical chemical characteristics (protein, fat, $\mathrm{pH}$ and density) and microbiological characteristics (reductase).

\subsection{Methodology}

\subsubsection{Detection of GMP by Electrophoresis}

The detection of GMP by electrophoresis was performed as described by Galindo,

Table 1. Scheme of the experiment.

\begin{tabular}{ccccc}
\hline Wheylevels & Code & Repets & SEU $^{*}$ & SEU/Treatment \\
\hline Control & T0 & 4 & 1 & 4 \\
$1 \%$ & T1 & 4 & 1 & 4 \\
$5 \%$ & T2 & 4 & 1 & 4 \\
$10 \%$ & T3 & 4 & 1 & 4 \\
$15 \%$ & T4 & 4 & 1 & 4 \\
Total & & & & 20 \\
\hline
\end{tabular}

${ }^{\star}$ Size of the Experimental Unit. 
et al. [6] and Alcázar, et al. [8], with some modifications, for which $50 \mathrm{ml}$ of each adulterated sample and of the control were taken. For protein precipitation, 25 $\mathrm{ml}$ of $24 \%$ trichloroacetic acid solution (TCA) was used, and shaking for $2 \mathrm{mi}$ nutes at room temperature, then left to stand for 60 minutes; subsequently, the precipitate of caseins and whey proteins was removed by filter paper filtration. $30 \mathrm{ml}$ of the $8 \%$ TCA filtrate was transferred and $8 \mathrm{ml}$ of $50 \%$ TCA solution was added to precipitate proteins which were not denatured during the previous step. Samples were kept at $4^{\circ} \mathrm{C}$ for 24 hours, then centrifuged at $7000 \mathrm{rpm}$ for 10 minutes; the obtained precipitate was washed with $10 \mathrm{ml}$ of a 1:1 ethanol-ether mixture, then centrifuged under the same conditions as above and then allowed to drain the tube to remove excesses from the wash mixture. After the precipitate was obtained, $380 \mu \mathrm{l}$ of buffer $0.05 \mathrm{M}$ TRIS-HCl +1 mM EDTA-Na $\mathrm{m}_{2} \mathrm{pH} 7.2$ and $500 \mu \mathrm{l}$ of a $50 \%$ sucrose solution and $0.002 \%$ bromophenol blue were used; the samples were stored at $4^{\circ} \mathrm{C}$ until they were subjected to SDS $0.375 \mathrm{M} \mathrm{pH} 8.8$ polyacrylamide gel electrophoresis at a concentration of $15 \%$ and at a constant voltage of $120 \mathrm{v}$ and 80 milliamperes for 45 minutes. Visualization of the protein bands was performed by staining the gels with $0.2 \%$ Coomasue R-250 blue in methanol:acetic acid:water (25:10:85) at room temperature for 6 hours; then decolorized in a solution of methanol:acetic acid:water (25:10:85). The area of the colored and extensive caseins it is the position between the 30 and $40 \mathrm{kDa}$ bands, whereas GMP was observed below $30 \mathrm{kDa}[6]$.

\subsubsection{Physico-Chemical Tests}

Milk protein: crude protein (CP) titration by the Kjeldahl method, based on the NTE INEN 16:84 [23].

Milk fat: the evaluation was made based on the Gerber Method, proposed in the NTE INEN 12:73 [24].

Density of the milk: it was made according to the established in the NTE 11:84 [25], through the method of the lactometer.

$\mathrm{pH}$ of the milk: the determination was made by direct reading by introducing the electrode of a $\mathrm{pH}$ meter, previously adjusted with buffers of known $\mathrm{pH} 4.00$ and 7.00, in the milk previously heated and homogenized at $40^{\circ} \mathrm{C}$ (to disperse the fat) and then cooled to $20^{\circ} \mathrm{C}$, based on the NTE 1500 [26].

\subsubsection{Microbiological Tests}

Reductase test: according to NTE INEN 18:73 [27] based on the methylene blue method.

\subsection{Statistical Analysis}

The physicochemical and microbiological characteristics were evaluated by analysis of variance and Duncan at $5 \%$.

\section{Results}

\subsection{GMP in Milk}

The presence of Glucomacropeptide in the milk of the control treatment (T0 
[negative control]) was negative, whereas in the milks in which the different whey levels were applied (1\%,5\%,10\% and 15\%) was positive in all cases, evidencing a band of $20.9 \mathrm{kDa}$ in the electrophoresis.

\subsection{Protein Percentage (\%)}

The average protein of the milk obtained in the present investigation was $3.24 \%$, with a coefficient of variation of $2.36 \%$, when performing the analysis of variance it was possible to determine there was no statistical difference between the treatments.

\subsection{Fat Percentage (\%)}

Milk including milk whey on average recorded 3.86\% of fat and a coefficient of variation of $1.38 \%$, when performing analysis of variance did not determine significant differences between different levels of whey in adulterated milk. When analyzing Figure $1(\mathrm{a})$, the fat content is significantly related $(\mathrm{P}<0.02)$ with whey levels, in this way it can be mentioned that $28.07 \%$ of milk fat depends on the inclusion of whey and for each percentage of inclusion of whey, the fat percentage is reduced by $0.005 \%$.

\subsection{Milk pH}

The milk pH included cheese whey on average was 6.67, with a coefficient of variation of $0.58 \%$; by subjecting the experimental results to the analysis of variance, it was possible to determine that there are significant differences between the different levels of whey. The use of $1 \%$ and $5 \%$ of whey allowed to register 6.73 and 6.70 of $\mathrm{pH}$, which differ significantly from the rest of whey milk levels,

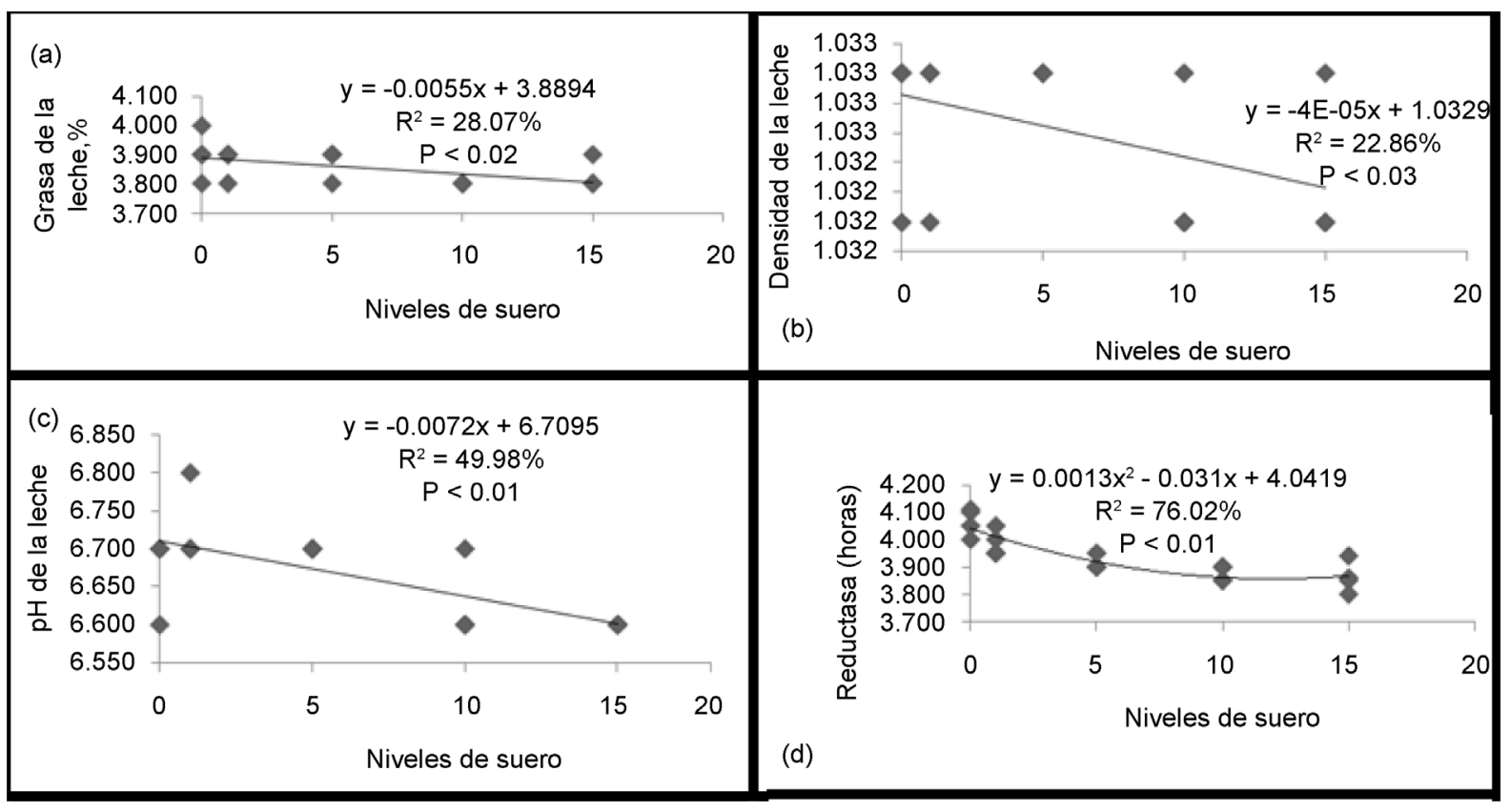

Figure 1. Physicochemical parameters of milk under the effect of the application of different levels of whey (a) Fat percentage; (b) $\mathrm{pH}$ percentage; (c) Density percentage; (d) Reductase percentage. 
mainly of $15 \%$ whey with which $6.60 \mathrm{of} \mathrm{pH}$ was reached. In Figure $1(\mathrm{~b})$ it is determined that the $\mathrm{pH}$ of the milk is significantly related to the whey levels included in the whole milk and $49.98 \%$ of $\mathrm{pH}$ depends on the application of whey and for the percentage of its inclusion, the $\mathrm{pH}$ is reduces in 0.007 , that is to say that as whey is included milk tends slightly to acidification.

\subsection{Milk Density}

On average, the milk density included cheese whey registered $1033 \mathrm{~g} / \mathrm{ml}$ with a coefficient of variation of $0.04 \%$; when the experimental results were submitted to the analysis of variance, it was possible to determine that no significant differences between the treatments were observed. When analyzing the experimental results, according to Figure 1(c), it is possible to show that the milk density is significantly related $(\mathrm{P}<0.03)$, with the whey levels included in the whole milk, thus we have that the density $22.86 \%$ of the milk depends on the whey levels applied, it being stated that for each percentage of whey included the density of milk reduces by $0.001 \mathrm{~g} / \mathrm{ml}$.

\subsection{Reductase}

According to the reductase analysis, the average milk recovered normal color at 3.94 hours, with a coefficient of variation of $1.12 \%$; when submitting the experimental results it was possible to notice that there are significant differences between the different treatments. When analyzing the milk without the application of whey, it takes 4.07 hours to recover its normal color, a value that differs significantly from other treatments, mainly $15 \%$ whey, which reached 3.86 hours in taking the natural color. According to Figure 1(d), the milk oxidation time was found to be significantly related $(\mathrm{P}<0.01)$ to a quadratic regression, and, $76.02 \%$ reductase was dependent on whey levels and per percentage of use of whey up to $10 \%$; it tends to reduce the time of reductase in 0.031 hours and to include levels higher than $10 \%$ of whey the reductase time increases again in 0.0013 hours.

\section{Discussion}

\subsection{GMP in Milk}

Milk is one of the most complete foods that exist in nature and has been consumed by man for many years. Since the milk industrialization and its derivatives began, the adulteration of this food was increased in order to obtain greater revenue. One of the most commonly used forms of milk adulteration is the addition of water and/or whey from the manufacture in fresh cheese rich in GMP.

This study shows that there was no presence of GMP in unadulterated raw milk belong to control group (To) due to the absence of this adulteration indicator that only allows identify the presence of serum in milk, as indicated by Alcázar, C., et al. [8] since it is not possible to find it in free form in milk unless it contains added whey. Positive results (from intentionally adulterated milk) coincide with Alcázar, C., et al. [8] who verified the presence of GMP as an indicator of dehydrated milk adulteration with cheese whey, and as mentioned by 
Galindo, C., et al. [6] as the method determines the adulteration of milk with whey at levels as low as $1 \%$, and who point out that GMP is evidenced as a 20.9 $\mathrm{kDa}$ band because it most likely represents a trimeric form of the peptide.

Other studies also determine the presence of GMP in milk, but by reverse phase high-performance liquid chromatography with mass spectrometry detection [28], and through the use of an immunoassay method, based on the detection of GMP by sandwich ELISA system Chavez, et al. [21], with conjugation of pure anti-GMP antibodies to a biotin ester; also GMP can be detected by HILIC (Hydrophilic Interaction Liquid Chromatography) optimization [29], by polyacrylamide gel electrophoresis and cellulose acetate strips by thiobarbituric acid and malachite green staining reactions [30] and by HPLC and SDS-PAGE as found in marketed milk in Mexico [20].

On the other hand, other studies indicate the presence of bands of 20.1 and 14 $\mathrm{kDa}$ corresponding to samples of pure GMP, the original immunogen, in different states of aggregation [31]. These protein bands were not observed in samples of unadulterated milk, indicating that there was no cross-reactivity, although these authors developed a method of analysis by immunoblot for the detection of GMP using anti-GMP polyclonal antibodies.

\subsection{Protein Percentage (\%)}

The average milk protein obtained in this research and shown in Table 2, is within the normal parameters (minimum of $2.9 \%$ ) established by the standard norm NTE INEN 9 [2], as indicated by Meyer [4], 3.2\% protein, Silva [7] 2.9\% 5.6\%, Alviar, J. [32] 3.7\%, Villegas [5] 2.8\% - 3.5\%, López [33] 3.5\%; with the aforementioned it can be pointed out that the protein content in the present study is within the normal parameters of milk.

Table 2. Physical-chemical, microbiological and organoleptic behavior of milk including four levels of whey $(1 \%, 5 \%, 10 \%$ and $15 \%)$.

\begin{tabular}{|c|c|c|c|c|c|c|c|c|c|c|c|c|c|}
\hline \multirow{3}{*}{$\begin{array}{c}\text { Variables } \\
\text { GMP }\end{array}$} & \multicolumn{10}{|c|}{ Wheylevels } & \multirow{3}{*}{$\mathrm{CV} \%$} & \multirow{3}{*}{ Average } & \multirow{3}{*}{$\begin{array}{l}\text { Sign } \\
*\end{array}$} \\
\hline & \multicolumn{2}{|c|}{ Control } & \multicolumn{2}{|c|}{$1 \%$} & \multicolumn{2}{|l|}{$5 \%$} & \multicolumn{2}{|c|}{$10 \%$} & \multicolumn{2}{|c|}{$15 \%$} & & & \\
\hline & $\mathrm{N}$ & $\mathrm{b}$ & $\mathrm{P}$ & $\mathrm{a}$ & $\mathrm{P}$ & $\mathrm{a}$ & $\mathrm{P}$ & $\mathrm{a}$ & $\mathrm{P}$ & A & & & \\
\hline Proteins (\%) & 3.28 & $\mathrm{a}$ & 3.20 & $\mathrm{a}$ & 3.20 & $\mathrm{a}$ & 3.30 & $\mathrm{a}$ & 3.20 & A & 2.36 & 3.24 & Ns \\
\hline Fat (\%) & 3.90 & $\mathrm{a}$ & 3.88 & $\mathrm{a}$ & 3.88 & $\mathrm{a}$ & 3.80 & $\mathrm{a}$ & 3.83 & A & 1.38 & 3.86 & Ns \\
\hline $\mathrm{Ph}$ & 6.68 & $\mathrm{ab}$ & 6.73 & $\mathrm{a}$ & 6.70 & $\mathrm{a}$ & 6.63 & $\mathrm{bc}$ & 6.60 & $\mathrm{C}$ & 0.58 & 6.67 & $* *$ \\
\hline Density (g/ml) & 1.033 & $\mathrm{a}$ & 1.033 & a & 1.033 & $\mathrm{a}$ & 1.032 & a & 1.032 & A & 0.04 & 1.033 & Ns \\
\hline Reductase test (h) & 4.07 & $\mathrm{a}$ & 3.99 & $\mathrm{~b}$ & 3.91 & c & 3.88 & $\mathrm{C}$ & 3.86 & $\mathrm{C}$ & 1.12 & 3.94 & $* *$ \\
\hline Color (points) & 5.00 & $\mathrm{a}$ & 4.91 & $\mathrm{a}$ & 4.84 & $\mathrm{a}$ & 4.50 & B & 4.13 & $\mathrm{C}$ & 2.03 & 4.68 & $* *$ \\
\hline Taste (points) & 4.99 & $\mathrm{a}$ & 4.90 & $\mathrm{a}$ & 4.83 & $\mathrm{a}$ & 4.49 & B & 4.12 & $\mathrm{C}$ & 2.04 & 4.67 & ** \\
\hline Smell (puntos) & 4.97 & $\mathrm{a}$ & 4.88 & $\mathrm{a}$ & 4.81 & $\mathrm{a}$ & 4.47 & B & 4.10 & $\mathrm{C}$ & 2.04 & 4.65 & $* *$ \\
\hline Total & 14.96 & $\mathrm{a}$ & 14.69 & $\mathrm{ab}$ & 14.49 & $\mathrm{ab}$ & 13.46 & $\mathrm{~B}$ & 12.34 & $\mathrm{~B}$ & 2.04 & 13.99 & $* *$ \\
\hline
\end{tabular}

Equal letters do not differ significantly according to Duncan at 5\%. CV\%: Coefficient of variation. N: Negative. P: Positive, Sign: Significance is defined as the ratio of the standard deviation to the mean. Ns: There are no significant differences $(\mathrm{P}>0.05) .{ }^{*}$ : Significant differences $(\mathrm{P}>0.05) .{ }^{* *}$ : Highly significant differences $(P>0.05)$. 
Other studies also show that milk adulterated with whey has average values of total protein $(3.25 \%$ - 3.75\%), total solids $(11.9 \%$ - 13\%) and other physicochemical parameters that are within normal limits established by Ecuadorian legislation [2], except in a sample, which is well below the minimum established by the regulations.

\subsection{Fat Percentage (\%)}

In relation to the average fat of the milk obtained in this study (Table 2), it is within the normal parameters (minimum 3\%) established by NTE INEN 9 [2], as indicated by Meyer [4] 3.7\%, Silva [7] 2.5\% - 6\%, Alviar, J. [32] 3.5\% - 6.1\%, López [33] 3.7\%; it is then pointed out that the fat content is within the normal parameters of the milk.

The results obtained in this study coincide with the results published by Araújo [28] in which the fat content is in an average of $3.6 \% \pm 0.1 \%$, in 3 repetitions of the presence of GMP in milk, and reported by Galindo, C., et al. [6] where adulterated milk with whey has fat values between $3.10 \%$ and $4.0 \%$, except in a sample, which is below the minimum established by the NTE INEN 9 [2].

\subsection{Milk pH}

As for the average of the results in relation to $\mathrm{pH}$ (Table 2), the data obtained are within the normal parameters indicated by Meyer [4], 6.6, Silva [7] 6.6 - 6.7, Alviar, J. [32] 6.5 - 6.6, López [33] $6.5-6.7$; it is then pointed out that the $\mathrm{pH}$ is within the normal parameters of milk, although statistically there was significant difference between treatments.

In the study by Araújo [28] of the determination of GMP in milk by liquid chromatography there were no alterations in milk acidity in 3 repetitions, with an average of $0.15 \% \pm 0.01 \%$ of acidity being present in all cases, milk within normal parameters and without significant difference between treatments.

\subsection{Milk Density}

The average milk density obtained in this research and shown in Table 2, is within the normal parameters $(1028-1033 \mathrm{~g} / \mathrm{ml})$ established by the NTE INEN 9 [2], as well as indicates Meyer [4] $1030 \mathrm{~g} / \mathrm{ml}$, Silva [7] $1028-1034 \mathrm{~g} / \mathrm{ml}$, López [33] 1028 - $1038 \mathrm{~g} / \mathrm{ml}$; with the above mentioned it can be indicated that the density obtained is within the normal parameters.

Our results coincide with those obtained in a study of presence of GMP in milk by liquid chromatography [28], where the density (in $\mathrm{g} / \mathrm{ml}$ ) is found in an average of $1030 \pm 0.002,1028 \pm 0.001$ and $1030 \pm 0.005$, in the 1 st, 2 nd and 3 rd repetitions, respectively.

\subsection{Reductase}

All microorganisms have a reducing power because they can eliminate oxygen, being the main ones Lactococcus, coliforms and Bacillus [33]. According to Carrión [34], the time it takes methylene blue from its oxidized form (blue) to re- 
duced (colorless) under controlled conditions is proportional to the sanitary quality of the milk, but does not indicate the number of microorganisms present; based on this, it classifies the milk according to the following values: good to excellent more than 8 hours, regular to good of 6 - 8 hours, acceptable 2 - 6 hours and bad less than 2 hours; with the aforementioned it can be pointed out that the microbiological conditions are within the acceptable parameters.

The results obtained in our research coincide with those recorded by Araújo [28], where the bacterial content and the tables were stable in the 3 treatments studied (average of $1.0 \times 10^{1} \mathrm{CFU} / \mathrm{ml} \pm 0.001$ ), but not with the study conducted by Bremer [35] where they determined the interference of the protease activity produced by bacteria of the genus Pseudomonas, as an indicator of milk adulteration with whey cheese.

\section{Conclusion}

The results obtained showed that the detection of glucomacropeptide by electrophoresis was positive in all samples of adulterated milk, evidencing a band of $20.9 \mathrm{kDa}$ in the reading, corresponding to the molecular weight of the GMP. The present study determined that the detection of GMP by electrophoresis is a sensitive and specific method able to detect GMP in adulterations with concentrations of up to $1 \%$ of whey, showing to be a robust method that could be used in the routine of the dairy industry, as well as evidenced that the milk adulterated with whey maintains constant its microbiological, physical and chemical characteristics without denoting the possible presence of adulterations; there are no significant differences between treatments, except for the $\mathrm{pH}$ that tends to decrease as the percentage of serum in the milk increases.

\section{Acknowledgements}

To the Polytechnic School of Chimborazo, mainly to the teachers of the College of Animal Sciences. To the College of Veterinary Medicine of the Central University of Ecuador, to their teachers and authorities.

\section{References}

[1] FAO-OMS (2011) Leche y Productos Lácteos. Segunda, Roma.

[2] de N. Inen, S.E. (2015) Leche Cruda: Requisitos. http://www.normalizacion.gob.ec/wp-content/uploads/downloads/2015/07/nte_ine n_009_6r.pdf

[3] de N. Inen, S.E. (2008) Determinación de suero de quesería en la leche fluida y en polvo. Método cromatografía líquida de alta eficacia. 2401:2008.

[4] Meyer, M. (1997) Elaboración de productos lácteos, Tercera. Trillas.

[5] Villegas de Gante, A. (2003) Los quesos mexicanos, Segunda. Chihuahua, México.

[6] Galindo, L., Valbuena, E. and Rojas, E. (2006) Standardization of Glycomacropeptide Detection with SDS-PAGE as a Milk Adulteration Index. Redalyc, 16, 308-314.

[7] Silva, G. (1998) Duodécimo curso Nacional de Fabricación de Quesos Naturales, Primera. México.

[8] Alcázar, C., Rosas, J., Jaramillo, C. and Peña, S. (1998) Detección de glucoma- 
cropéptido (GMP) como indicador de adulteración con suero de quesería en leche deshidratada. Universidad Nacional Autónoma de México.

[9] Baieli, M., Urtasun, N., Martinez, M., Hirsch, D., Pilosof, A., Miranda, M., Cascone, O. and Wolman, F. (2017) Affinity Chromatography Matrices for Depletion and Purification of Casein Glycomacropeptide from Bovine Whey. Biotechnology Progress, 33, 171-180. https://doi.org/10.1002/btpr.2404

[10] Campos Mottaa, T.M., Hoffa, R.B., Barretob, F., Andradeb, S., Lorenzinib, D.M., Meneghinib, L.Z. and Pizzolatoa, T.M. (2014) Detection and Confirmation of Milk Adulteration with Cheese Whey Using Proteomic-Like Sample Preparation and Liquid Chromatography-Electrospray-Tandem Mass Spectrometry Analysis. Talanta, 120, 498-505. https://doi.org/10.1016/j.talanta.2013.11.093

[11] Requena, P., Daddaoua, A., Guadix, E., Zarzuelo, A. and Suárez, M.D. (2009) Bovine Glycomacropeptide Induces Cytokine Production in Human Monocytes through the Stimulation of the MAPK and the NF- $\kappa$ B Signal Transduction Pathways. British Journal of Pharmacology, 157, 1232-1240. https://doi.org/10.1111/j.1476-5381.2009.00195.x

[12] Daddaoua, A., Zarzuelo, A. and Sua, D. (2005) Bovine Glycomacropeptide Is Anti-Inflammatory in Rats with Hapten-Induced Colitis. Journal of Nutrition, 135, 1164-1170.

[13] Dalbeth, N., Gracey, E., Pool, B., Callon, K., Mcqueen, F.M., Cornish, J., Macgibbon, A. and Palmano, K. (2010) Identification of Dairy Fractions with Anti-Inflammatory Properties in Models of Acute Gout. Annals of the Rheumatic Diseases, 69, 766-769. https://doi.org/10.1136/ard.2009.113290

[14] López-Posadas, R., Requena, P., González, R., Suárez, M.D., Zarzuelo, A., de Medina, F.S. and Martínez-Augustin, O. (2016) Bovine Glycomacropeptide Has Intestinal Antiinflammatory Effects in Rats with Dextran Sulfate-Induced Colitis. Journal of Nutrition, 140, 2014-2019.

[15] Guilloteau, P., Romé, V., Delaby, L., Mendy, F., Roger, L. and Chayvialle, J.A. (2010) Is Caseinomacropeptide from Milk Proteins, an Inhibitor of Gastric Secretion? Regulatory Peptides, 159, 129-136.

[16] Ney, D.M., Hull, A.K., Van Calcar, S.C., Liu, X. and Etzel, M.R. (2008) Dietary Glycomacropeptide Supports Growth and Reduces the Concentrations of Phenylalanine in Plasma and Brain in a Murine Model of Phenylketonuria. Journal of Nutrition, 138, 316-322.

[17] LaClair, C., Ney, D., Macleod, E.L. and Etzel, M. (2009) Purification and Use of Glycomacropeptide for Nutritional Management of Phenylketonuria. Journal of Food Science, 74, E199-E206.

[18] Van Spronsen, F.J. and Enns, G.M. (2010) Future Treatment Strategies in Phenylketonuria. Molecular Genetics and Metabolism, 99, S90-S95. https://doi.org/10.1016/j.ymgme.2009.10.008

[19] Muñoz, F.C., Cervantes, M.M., Cervantes-García, D., Jiménez, M., Ventura-Juárez, J. and Salinas, E. (2017) Glycomacropeptide Attenuates Inflammation, Pruritus, and Th2 Response Associated with Atopic Dermatitis Induced by 2,4-Dinitrochlorobenzene in Rat. J. Immunol. Res., 2017, Article ID: 6935402.

[20] Reyes, J., Bon, F., Moreno, J., Rubio, C. and Valdivia, A. (2007) Adulteración de leche pasteurizada con suero de quesería en la ciudad de Aguascalientes. Avances en Investigacion Agropecuaria, 11, 23-34.

[21] Chávez, N.A., Salinas, E., Jáuregui, J., Palomares, L.A., Bon, F., Rodríguez, J., Bioquímica, D.D.I., Básicas, C.D.C., De, U.A., Universidad, M.A. and México, A. (2010) Detección mediante un sistema ELISA de glucomacropéptido (GMP) como 
índice de adulteración de leche con suero de quesería. Universidad Autónoma de Aguascalientes, Aguascalientes, México.

[22] S. E. de N. INEN (2008) Leche y productos lácteos: Muestreo. http://www.normalizacion.gob.ec/wp-content/uploads/downloads/2013/11/rte_4_4. pdf

[23] S. E. de N. INEN (1983) Leche. Determinación de proteinas 16: 1983.

[24] S. E. de N. INEN (1973) Leche. Determinación del contenido de grasa 12: 1973.

[25] S. E. de N. INEN (1983) Leche. Determinación de la densidad relativa 11: 1983.

[26] S. E. de N. INEN (2011) Leche. Métodos de ensayo cualitativos para la determinación de calidad 1500: 2011.

[27] S. E. de N. INEN (1973) Leche. Ensayo de reductasa.

[28] Araújo, M. (2008) Determinacao de farude de leite con soro de leite pela análise de CMP e pseudo-CMP por cromatografia líquida de alata eficiencia em fase reversa com deteccao por espectrometria de massa. Iniversidade Federal de Vicosa.

[29] Hernandez-Hernandez, O., Lebron-Aguilar, R., Quintanilla-López, J.E., Sanz, M.L. and Moreno, F.J. (2010) Development of a New Method Using HILIC-Tandem Mass Spectrometry for the Characterization of O-Sialoglycopeptides from Proteolytically Digested Caseinomacropeptide. Proteomics, 10, 3699-3711. https://doi.org/10.1002/pmic.201000156

[30] Nakano, T., Ikawa, N. and Ozimek, L. (2007) Detection of Sialylated Phosphorylated $\kappa$-Casein Glycomacropeptide Electrophoresed on Polyacrylamide Gels and Cellulose Acetate Strips by the Thiobarbituric Acid and Malachite Green Dye Reactions. Journal of Agricultural and Food Chemistry, 55, 2714-2726. https://doi.org/10.1021/jf062987f

[31] Chávez Vela, A., Salinas Miralles, E., Jáuregui Rincón, J., Palomares Aguilera, L.A. and Bon Rosas, F. (2009) Desarrollo de un método inmuno blot para detectar glucomacropéptido (GMP) como índice de adulteración de leche de vaca con suero de quesería. Investigación y Ciencia de la Universidad Autónoma de Aguascalientes, 43, $16-20$.

[32] Alviar, J. (2010) Manual Agropecuario. Técnicas orgánicas de la granja integral autosuficiente. Segunda, Bogotá-Colombia.

[33] López, A. (2003) Manual de Industrias Lácteas. Primera Ed., Madrid.

[34] Carrión, A. (2008) Influencia de los diferentes grados de mastitis sobre el porcentaje de materia grasa, densidad, acidez, ph y reductasa de leche receptada en lácteos San Antonio. Escuela Superior Politécnica de Chimborazo, Riobamba, Ecuador.

[35] Bremer, G. (2009) Detecção da Adição Fraudulenta de Soro de Queijo em Leite: Interferência da Atividade de Proteases Bacterianas. Universidade Federal Rural Do Rio de Janeiro. 
Submit or recommend next manuscript to SCIRP and we will provide best service for you:

Accepting pre-submission inquiries through Email, Facebook, LinkedIn, Twitter, etc. A wide selection of journals (inclusive of 9 subjects, more than 200 journals)

Providing 24-hour high-quality service

User-friendly online submission system

Fair and swift peer-review system

Efficient typesetting and proofreading procedure

Display of the result of downloads and visits, as well as the number of cited articles Maximum dissemination of your research work

Submit your manuscript at: http://papersubmission.scirp.org/

Or contact fns@scirp.org 